\title{
Margaret McCartney: Misinformation in the EU debate
}

\author{
Margaret McCartney, general practitioner
}

Glasgow

I like facts, and I love evidence-bring it on. "Official information about the referendum," says one leaflet, pushed through the door because I'm "someone who cares about the future of Scotland and fair access to public services."

A sum equivalent to building a new hospital, £350m ( $€ 442 \mathrm{~m}$; $\$ 496 \mathrm{~m})$, is spent each week on our EU membership. Five new countries are "in the queue" to join the European Union, and I have to decide "whether this will help Scotland . . . and fair access to public services." It has graphs of increasing "billions sent to the EU," as well as pointed illustrations of Turkey being next to Syria and Iraq. In small writing, it declares itself to be published by the Scottish Vote Leave campaign.

What is trustworthy-that which is "official"? On the mat I also found a leaflet with the royal coat of arms, complete with lion and unicorn, in the same typeface as other "official" government publications. Should I therefore believe it more readily? "The government believes it is in you and your family's best interests that the UK remains in the European Union," it states. Why, then, is the government having a referendum at all? It is, of course, a painful compromise of internal party politics.

Which one to believe? The $£ 350 \mathrm{~m}$ figure is simply wrong, says the "official" UK Statistics Authority, ${ }^{1}$ by $£ 100 \mathrm{~m} .{ }^{2}$ I trust this advice more. Yet that figure has appeared on all of the Brexit leaflets through my letterbox, as well as the one from the Electoral Commission. That leaflet also contained information from the Bremain campaign, saying that, for every $£ 10$ we put in, "we get almost $£ 10$ back in lower prices, more jobs and more investment." The source, infuriatingly, was cited as "HMT, CBI" which I presume are the Treasury and the Confederation of Business Industry, and in two hours of online searching I found nothing resembling a rational, understandable explanation of what is fact and what is approximation. (How long would it take to add hyperlinks on "official" campaign websites? Isn't that what the internet is for?)

Misinformation on the EU flies as frequently and viciously as the Scottish summer midge. Survey data show that we overestimate the amount of immigration to the United Kingdom and overestimate how much child benefit is sent abroad; that we don't usually know who our MEP is but do know that we put in more, in monetary terms, than we get back; and overestimate how much we pay, compared with other countries. ${ }^{3}$ What, then, to go on? I wouldn't wish to leave a union where the NHS and research community benefit from close ties with colleagues across the EU. Neither side cites evidence well, but the Brexit campaign is using fear mongering about immigration — which, given the ongoing Mediterranean humanitarian disaster, ${ }^{4}$ is unforgivable. We should not want to be Little Britain.

1 UK Statistics Authority. UK Statistics Authority statement on the use of official statistics on contributions to the European Union. 27 May 2016. https://www.statisticsauthority.gov. uk/news/uk-statistics-authority-statement-on-the-use-of-official-statistics-on-contributionsto-the-european-union/.

2 Full Fact. EU facts behind the claims: the membership fee. 13 Apr 2016. https://fullfact. org/europe/membership-fee-eu/.

3 Ipsos MORI. The perils of perception and the EU. 9 Jun 2016. https://www.ipsos-mori. com/researchpublications/researcharchive/3742/The-Perils-of-Perception-and-the-EU. aspx.

4 Médecins Sans Frontières. Mediterranean migration. 20 May 2016. www.msf.org/en/ topics/mediterranean-migration.

Published by the BMJ Publishing Group Limited. For permission to use (where not already granted under a licence) please go to http://group.bmj.com/group/rights-licensing/ permissions 